\title{
Az iskoláskorú tehetséges olvasók: pszichológiai jellemzők és fejlesztési lehetőségek
}

Döbör Ágota, Szegedi Tudományegyetem Juhász Gyula Pedagógusképző Kar, TOKI,

Alkalmazott Pedagógia és Pszichológia Tanszék

doboragota@jgypk.u-szeged.hu

Hódi Ágnes, Szegedi Tudományegyetem Oktatáselméleti Kutatócsoport

agnes.hodi@edu.u-szeged.hu

Dr. Habil. Dávid Imre PhD Debreceni Egyetem Pszichológai Intézet

davidi@vipmail.hu

\section{ÖSSZEFOGLALÓ}

Az olvasásfejlődés és -fejlesztés területe világszerte számos diszciplína által kutatott terület, hiszen az egyén olvasási képességének optimális fejlettsége képezi az iskolai és társadalmi boldogulás egyik fő alappillérét. Az olvasást tanult készségként tartják számon, azonban az azt megalapozó (háttér) kognitív készségek jóval a formális oktatás kezdete előtt kialakulnak, így az olvasásfejlesztő és intervenciós programok nagy része ezen életkori szakaszra összpontosít. Tendenciaként rajzolódik ki, hogy a programok a fejlődési rendellenességek által okozott lemaradást igyekeznek kiküszöbölni, illetve a tipikus fejlödési ívü, azonban az átlagostól gyengébben teljesítő tanulók felzárkóztatására koncentrálnak, háttérbe szorítva a kiemelkedő és tehetséges olvasók korai beazonosítását és fejlesztését. Napjainkban egyre több nemzetközi vizsgálat ötvözi a tehetségpszichológia modelljeit az olvasáskutatások eredményeivel gyarapítva ezzel a tehetséges olvasóról szerzett ismereteket. Az olvasásszövegértés fejlettségi szintjének meghatározásához számos mérőeszköz áll rendelkezésre, azonban a tehetséges olvasó diagnosztizálásához nem elegendő csupán a tanulói teljesítmény ismerete. Tanulmányunk elsődleges célja, hogy ismertessük egy kevéssé vizsgált terület, az olvasásában tehetséges gyermekekkel kapcsolatos kutatások legfontosabb eredményeit, bemutassuk a tehetség definícióit, értelmezéseit, valamint módszertani összefoglalót adjunk a tehetséges olvasó fejlesztési lehetőségeiről.

kulcsszavak: tehetség, tehetséges olvasó, olvasás-szövegértés, speciális olvasásfejlesztö programok 
Az olvasás-szövegértés ${ }^{1}$ alapvető szerepet játszik minden gyermek fejlödésében, hiszen az nem csak az általános és középiskolai teljesítményt befolyásolja, de meghatározza a mindennapi életben való boldogulást is, azaz az e területen elért jó teljesítmény alapfeltétele a továbbhaladásnak, míg az alacsony teljesítmény gyakorlatilag minden más területre kedvezőtlen hatással van. Hazánk az 1970-es évektől kezdve veszt részt nemzetközi nagymintás, a magyar tanulók - többek között - olvasás-szövegértésére irányuló teljesítménymérési programokban (pl. IEA PIRLS, OECD PISA). Az iskoláskorú gyermekek olvasásteljesítményéről ugyanakkor a különböző életkorokban felvett vizsgálatok eredményei más-más tendenciát mutatnak. Míg például a PIRLS vizsgálat eredményei szerint a 9-10 éves magyar tanulók olvasása jó, s a nemzetközi rangsorban ciklusról-ciklusra előkelőbb helyet foglal el (Mullis et al., 2004, 2007), addig a PISA eredményei azt mutatják, hogy a 15 éves tanulók olvasása nagyon gyenge, jóval az OECD országok átlaga alatt helyezkedik el (OECD, 2001, 2010). A fentebb említett mérések adatai által is érzékeltetett, az utóbbi évtizedekben bekövetkező olvasástechnikai és szövegértési hanyatlás (ld. PISA sokk) emelte az olvasásfejlesztést ismét a tudományos kutatások és az oktatáspolitika látókörébe. Napjainkban számos vizsgálat irányul az olvasás-szövegértést akadályozó tényezők feltérképezésére az iskoláskorú gyermekektől a felnőtt populációig (pl. OECD International Adult Literacy Survey - Nemzetközi Felnőtt Írásbeliségvizsgálat). A közoktatás első szakaszában követi nyomon a gyermekek olvasás-szövegértésének fejlődését az egy évtizede indított hazánkban egyedülálló követéses vizsgálat a Szegedi Iskolai Longitudinális Program is (Csapó, 2007), amelynek célja, hogy feltérképezze, hogy mely demográfiai, kognitív vagy affektív tényezők befolyásolják, illetve jósolják meg az olvasásteljesítményt.

Fontos azonban, hogy a célzott olvasásfejlesztési módszereket nem csak a gyengébb olvasók esetében lehet és kell alkalmazni felzárkóztatás céljából, hanem a jobb olvasási képességü, meghatározott pszichológiai attribútumokkal bíró, avagy tehetséges gyermekek „szárnyaltatására” is léteznek kutatás-alapú, megbízható és validált fejlesztő programok.

\footnotetext{
${ }^{1}$ Különböző szakirodalmak más-más terminológiát használnak az olvasás-szövegértés képességének jelölésére: olvasási képesség, olvasás-szövegértés, olvasás, mint eszköztudás (reading literacy). Jelen tanulmány keretein belül az olvasás-szövegértés alatt a nemzetközi és hazai tanulói teljesítménymérések tartalmi kereteiben meghatározott definíciót értjük, amely szerint az olvasás-szövegértés az ,írott szövegek megértésének, használatának és értékelésének képessége annak érdekében, hogy az egyén képes legyen céljai elérésére, tudásának fejlesztésére és a társadalmi életben való részvételre” (OECD, 2000).
} 
Míg tehetségkutatással már az ókorban is foglalkoztak, s a tehetség fogalma az évszázadok során folyamatosan bővült, változott, a tehetséges olvasó beazonosítása és oktatási szükségletei az elmúlt évtizedek kutatási eredményeinek köszönhetően kerültek a figyelem középpontjába. Ennek következtében kevés azon tanulmányok és fejlesztőprogramok száma, amelyek a tehetséges olvasó témáját, illetve oktatási szükségleteit állítják középpontba. A tehetséges olvasó hazánkban is keveset vizsgált terület, így különösen indokoltnak bizonyult egy szakirodalmi összefoglaló, amely szintetizálja a releváns hazai és nemzetközi eredményeket s törekszik a fogalmi zavarok tisztázására.

Jelen tanulmányban két napjainkban kiemelkedő fontosságú kutatási terület, az olvasásszövegértés és a tehetség pszichológiája közös keresztmetszetét, azaz a tehetséges olvasó fogalmát mutatjuk be. Tanulmányunk célja, egyrészről, hogy összefoglalót nyújtsunk a tehetséges olvasó témakörrel foglalkozó - föként amerikai és angolszász - kutatásokról, másrészről, hogy megismertessük a tehetséges olvasó definícióját, pszichológiai jellemzőit és speciális oktatási-fejlesztési szükségleteit.

\section{Tehetségkutatás a kezdetektől napjainkig}

A tehetséghez való viszonyulás az idők folyamán sokat változott. Meghatározta az aktuális történelmi, politikai, vagy éppen gazdasági helyzet. Már az ókori görögök is foglalkoztak a tehetséges emberek meghatározásával, ethusziaszmosz kifejezéssel illették őket. Az ókori Kínában a tehetséges, azaz a „csodagyerekeket” a nemzet boldogulásának eszközeként kezelték, felkutatták őket, és ha a császár is úgy ítélte meg, ösztöndíjban részesültek. (Páskuné, 2002)

A tehetség tudományos kutatása a XIX. században indult meg. Galton öröklődés alapú elméletében kidolgozta az intelligenciabeli egyéni különbségek genetikai modelljét. A természetes szelekció elméletét átültette az értelmi képességek öröklődésének elméletébe. A szülők és utódaik közti kapcsolatok tanulmányozása során felfedezte az átlaghoz való visszatérés jelenségét. (Páskuné, 2002; Tóth, 1996, 2003; Balogh, 2004; Czeizel, 1997).

Az intelligencia és a tehetség fogalma és kutatása sok tekintetben összefonódik. Néhány elmélet komoly hatást gyakorolt a tehetség értelmezésére. Ilyen Spearman g-faktor elmélete, Thurstone elmélete az elsődleges mentális képességekről, Cattell elmélete a fluid és kristályos intelligenciáról, Guilford háromdimenziós intelligencia modellje, Sternberg elmélete a hármas 
alapú intelligenciáról, valamint Gardner elmélete a többféle intelligenciáról (Páskuné, 2002; Tóth, 1996, 1998, 2003; Balogh, 2004; Czeizel, 2000).

Kezdetben a magas intelligenciát tekintették a tehetség jellemzőjének. Alapkutatásnak számít Lewis Terman 1921-ben, 1500 nagyon magas intelligenciájú gyermek részvételével indított követéses vizsgálata. Az eredmények azt bizonyították, hogy a gyermekkorban mutatott kiemelkedő képességek nem feltétlenül biztos jelei a későbbi kiemelkedő teljesítménynek. (Balogh, 2004; Czeizel, 1997; Páskuné, 2002).

A későbbiekben új irányt vettek a kutatások, hiszen kiderült, hogy a magas intelligencia csak egy a tehetséget alkotó számos összetevő közül. Első komponensként a kreativitás és a magas teljesítmény lépett be (Scheifele), majd egyre több speciális képesség árnyalta a definíciót (Otto, DeHaan és Havighurst). (Mező és Miléné, 2003; Balogh, 2004)

A modern tehetségkutatás egyik legjelentősebb állomásaként 1977-ben Joseph Renzulli (2002) megfogalmazta az ún. „három körös” tehetség koncepcióját. Ettől kezdve nyilvánvalóvá vált, hogy a tehetséget nem lehet egyetlen kritérium alapján meghatározni.

Renzulli három komponensben határozta meg, hogy ki tehetséges. Ezek az átlagon felüli (intellektuális) képességek - melyet később általános és specifikus képességekre bontott -, a feladat iránti elkötelezettség (legfontosabb összetevői: az érdeklödés, kitartás, önbizalom, énerő és kritikus gondolkodás) és a kreativitás.

Ezután egyre több modell jelent meg, egyre szélesebb definícióját adva a meghatározásnak. A modern elméletek közül érdemes kiemelni Franz Mönks 1997-ben megalkotott többtényezös tehetségmodelljét, melynek alapgondolata, hogy a tehetség kibontakozásához több tényező interakciójára van szükség. Renzulli három körös modelljét kiegészítve egyrészt személyen kívüli, környezeti tényezöket (család, iskola, kortársak) emel be a modelljébe, másrészt a különleges képességek kategóriáját is kibővíti a motorikus, társadalmi és művészi képességekkel. Így - Renzulli modelljével ellentétben - már nem csak a magas intellektuális képességekkel, hanem a kiemelkedő művészi vagy motorikus adottságokkal rendelkezők is „beférnek” a tehetséges dimenzióba. (Balogh, 2004; Czeizel, 1997; Tóth, 2003; Mönks, 1998, 2000; Páskuné, 2002).

Szintén alapvető a témában Françoys Gagné munkája. A kanadai pszichológus a tehetség adottságai és teljesítménye alapján való meghatározása között tesz különbséget. „Megkülönböztető” modelljében az adottságokat szunnyadó tehetségnek nevezi (giftedness), a megvalósult tehetségre pedig a talentum (talent) kifejezést használja. Gagné modellje szerint az adottságok megvalósult tehetséggé való fejlődéséhez környezeti és interperszonális katalizátorokra van szükség; ugyanakkor a tanulásnak, gyakorlásnak is szerepe van a 
folyamatban. A gyakorlatban mindez azt jelenti, hogy hiába születik valaki kivételes adottságokkal, szunnyadó tehetséggel (giftedness), ha nincs elég motivációja, akarata és kitartása a gyakorláshoz (intraperszonális katalizátor); illetve nincsen támogató környezete (család vagy iskola stb.) (környezeti katalizátor), akkor nem lesz képes tehetségét kibontakoztatni, soha nem lesz megvalósult tehetség (talent). A legújabb kutatási eredmények azt mutatják, hogy a veleszületett adottságoknak csekély szerepe van a kivételes teljesítményben a többi tényezőhöz képest (Balogh, 2004; Páskuné, 2002; Khatena, 1992; Gagne, 2004).

A hazai kutatók közül (a kezdeti kutatók mellett, mint pl. Révész Géza, Nagy László, Szittnyai Elek) Czeizel Endre nevét érdemes kiemelni, aki 2x4+1 faktoros elméletében számos tényezőt integrál. Renzulli és Mönks munkáját fejleszti tovább, az azokban megtalálható személyen belüli és kívüli tényezők mellé negyedik környezeti tényezőként megjelenik a társadalom, mely Czeizel szerint az elvárásokon, az aktuális lehetőségeken és a közvetített értékrenden keresztül szintén markánsan meghatározza a tehetség kibontakozásának lehetőségét. Kilencedik $(a z a z+1)$ faktorként megjelenik a sors, vagy más néven az élet-egészség faktora, ugyanis Czeizel szerint a tehetség kibontakozásának előfeltétele, hogy bizonyos kort egészségesen megéljen az ember (Balogh, 2004; Czeizel, 1997, 2000).

Ahogy a tehetségmodellek áttekintéséből is kiderült, a definíció folyamatosan bővült, alakult. Ma a tehetség fogalmát gyüjtőfogalomnak tekinthetjük.

A tehetség meghatározására irányuló kutatások után indultak be a tehetségspecifikumokra, illetve az egyes tehetségtípusok jellemzőire (pl. sport, zenei, matematikai tehetség, vagy az általunk is vizsgálni kívánt olvasásban tehetségesek csoportja) irányuló kutatások. Ezek tekinthetők napjaink hazai tehetségkutatásai irányzatainak is.

\section{Az olvasás-szövegértés szintjei: kiemelkedő teljesítmény avagy tehetség?}

Az értő olvasás elsajátítása számos készség és képesség optimális fejlettségét feltételező folyamat (Nagy, 2006), amely elméleti szempontból két jól elkülöníthető részre bontható: formális (dekódolás) és tartalmi (megértés) (Gósy, 2008). A dekódolás a szavak belső szerkezetéhez való tudatos hozzáférés, a szavak eltérő méretű egységeire történő bontás, a betüknek a megfelelő beszédhangokkal történő megfeleltetés, valamint a szószegmentálás képességét jelöli, míg a megértés középpontjában a jelentésazonosítás és a jelentéshez való 
hozzáférés áll. E pszichológiai és alkalmazási komponenseknek a mérése az olvasás diagnosztikus értékelése terén több évtizedes hagyománnyal rendelkezik (Csapó et al., 2012). „Az olvasási készség fejlettsége a betűismeret, a dekódolás, a szóolvasás pontossága és folyékonysága mentén, valamint a szavak és álszavak olvasásán keresztül térképezhető fel” (Józsa, 2012. 223. o.), míg a szövegértés szintjét azon keresztül mérik, hogy a tanulók hogyan tudják a különböző formájú és típusú szövegekben található információt visszakeresni, értelmezni és értékelni annak érdekében, hogy képesek legyenek céljaik elérésére, tudásuknak fejlesztésére és a társadalmi életben való részvételre (Csíkos, 2006..; OECD, 2013.).

Bár az olvasáskomponensek fejlődése részben egymással párhuzamos, látható, hogy az olvasásfejlődés különböző szakaszaiban más-más jellemzőkkel írható le, hogy ki a jó olvasó. Hétköznapi értelemben véve a jó olvasó az, aki az átlagosnál jobb teljesítményt nyújt különböző olvasásteszteken vagy az a gyermek, aki folyékonyan és hiba nélkül olvas ki szavakat, mondatokat és különböző hosszúságú szövegeket. Tudományos megközelítésből ennél árnyaltabb képet kapunk a jó olvasóról, hiszen az gyermek, aki jól és gyorsan tud mechanikusan olvasni, nem biztos, hogy szövegértési képességeit is képes kamatoztatni. Így a tanulmány tárgyát képező, a szakirodalomban tehetséges (talented reader) olvasóként említett gyermekek jellemzőinek megértéséhez szükséges a definíciót megkülönböztetnünk az olvasás tipikus fejlődési ívével járó jó olvasó (good reader) és a korai olvasó (precocious reader) fogalmától, de szót ejtünk egy kapcsolódó atipikus fejlődési rendellenességröl, a hiperlexiáról is.

A ,jó olvasó” jellemzőinek feltérképezésére számos nemzetközi kutatás irányult. Az Egyesült Államokban az elmúlt évtizedekben végzett felmérések alapján szakértők megállapították, hogy a jó olvasó egyén pozitív attitüddel rendelkezik az olvasás iránt, folyékonyan és hibátlanul olvas, hogy az olvasottak értelmezésére fókuszálhasson a dekódolás helyett, valamint háttértudását képes integrálni az olvasott tartalommal. Ezek a tényezők lehetővé teszik, hogy a jó olvasó következtetéseket vonjon le a szövegből, valamint az olvasottak jelentését a szöveg kritikai értékelésével árnyalja, elvonatkoztassa, kiterjessze és alakítsa. A jó olvasó az, aki különböző formájú és típusú szövegeket képes elolvasni és értelmezni különböző célok elérése érdekében hatékony olvasási stratégiák használatával (NAEP, 1998; Valencia és Pearson 1987; Brown és Pressley, 1994). 
Az olvasáskutatások a jó olvasó fogalmát az olvasás-szövegértéshez használt stratégiák mennyiségéhez és minőségéhez, valamint az olvasáshoz való pozitív hozzáálláshoz kötik, így jelen tanulmányban a fogalmi tisztaság érdekében e definíciót nem használjuk a tehetséges olvasó szinonímájaként. A tehetséges és a korai olvasó elkülönítése kényes feladat, nehezítő tényező, hogy a szakirodalom sem teljesen egységes a meghatározásban. Egyesek a korai olvasót a tehetséges olvasóval azonosítják (Fogarty, 2009), mások pedig a hiperlexia egyik változatának tekintik (Treffert, 2011). A definíciók alapján lehet olyan tehetséges olvasó, aki nem korai olvasó, és lehet olyan korai olvasó, akiből nem lesz tehetséges olvasó, ám a kettő együtt is járhat. Tanulmányunk elsősorban a tehetséges olvasók csoportjára koncentrál, de a fogalmi pontosság érdekében bemutatjuk a korai olvasók jellemzőt, és szót ejtünk a már említett hiperlexiás gyermekekről is.

Korai olvasónak tekinthető egy gyermek, ha 5 éves kora elött magától megtanul olvasni. A formális oktatás első szakaszába történő belépés kezdetén, egy tipikus olvasás-fejlődési ívü gyermek be tudja azonosítani a szó elején lévő grafémákat és fonémákat, míg egy korai olvasó szavakat, mondatokat olvas ki. Ebben az esetben a későbbi fejlődési ívröl nem adhatunk bejóslást, akár utol is érhetik társai, kezdeti előnyét elvesztve átlagos olvasóvá válhat. Bár a korai olvasás kialakulása és a hátterében álló kognitív folyamatok még nem tisztázottak, a jelenséget a tengerentúlon már több mint két évtizede a tehetség egyik megnyilvánulási formájaként tartják számon s széles körben elfogadott, hogy a korai olvasókat már az általános iskola első szakaszában kiemelt fejlesztésben kell részesíteni (Fogarty, 2009).

A hiperlexiás gyermekek olyan kiemelkedően gyors mechanikus olvasási készséggel rendelkeznek, amely gyenge szövegértéssel párosul (Tóth és Csépe, 2008). E fejlődési rendellenességgel rendelkező gyermekek már iskolába lépés előtt megtanulnak olvasni. Csépe Valéria szerint ,a hiperlexia a szakemberek számára éppolyan figyelmeztető jele a fejlődési rendellenességnek, mint ellentéte, a diszlexia" (idézi Nahalka és Mózessy, 2011. 153. o.). A nemzetközi szakirodalomban több változatát írják le a hiperlexiának. Az egyik típusa a már említett korai olvasóval szinoníma, másik típusa az autizmus spektrumon elhelyezkedő rendellenesség, ugyanis ilyenkor a korai mechanikus olvasás egy szigetszerü képességként jelenik meg, és egyéb, az autizmusra jellemzö hiányok (nyelvi és szociális) társulnak hozzá (Treffert, 2011). Ezzel szemben akkor beszélhetünk tehetséges olvasóról, amikor a gyermek olvasási képességének (technikai és megértési) fejlettségi szintje jóval (kb. 2 év) fejlettebb a hasonló korosztályú társaikéhoz képest. 


\section{A tehetséges olvasó pszichológiai jellemzői}

A releváns kutatások definiálni kívánják az olvasás terén tehetséges gyerekeket, illetve összegyüjteni a tehetséges olvasók és szövegértők jellemzőit. Több szerző egyetért abban (Collins és Kortner, 1995; Halsted, 1990), hogy a tehetséges olvasók korábban olvasnak, mint kortársaik, több időt töltenek olvasással, és az általuk elolvasott irodalmi művek nagy változatosságot mutatnak. Ezek a tanulók jóval (2-3 évvel) az életkori sajátosságok alapján elvárható szint felett olvasnak, jobb nyelvi megértést mutatnak, kiterjedt szókincset használnak, a jelek és szimbólumok közti kapcsolatok megértésében ügyesebbek kortársainál. Továbbá a tehetséges olvasóknál feltünő a könyvek szeretete, majd a későbbiekben atlaszok, szótárak, enciklopédiák gyakori használata, és a komplex fogalmak korábbi megértése. (Moore, 2005; Terman, 1925, idézi Tóth, 1998; Catron és Wingenbach, 1986; Dooley, 1993; Witty, 1955, idézi Tóth, 1998; VanTassel-Baska, 1983, idézi Balogh, 2004) Mivel olvasási stratégiáik is megelőzik kortársaikét, így a hagyományos olvasástanítás sem megfelelő számukra, ezért magasabb szintről indulva, másfajta oktatási módszerrel fejleszthetők. (Erre több kísérleti modell is készült, ezek közül kettőt a későbbiekben röviden megemlítünk: Karnes és McBride, 1978; Reis és Gubbins, 2003).

Passow (1981, idézi Reis és Gubbins, 2003) szerint az óriási változatosság ellenére, amit a tehetséges gyerekek mutatnak, van számos olyan vonás, ami megkülönbözteti őket átlagos társaiktól. A legtöbb kutatás leszögezi, hogy a tehetségesek általános tanulási jellemzőikben több tekintetben is különböznek általános társaiktól: általában gyorsabban tanulnak, a problémákat könnyebben megtalálják, megfejtik és megoldják; fejlett a gondolkodásuk, valamint könnyebben megértik és összekapcsolják az absztrakt fogalmakat. (Feldhusen, 1986; Gallagher, 1985; Keating; 1976; Renzulli és Smith, 1978; Sternberg, 1985 idézi öket: Reis és Gubbins, 2003).

Mason és Au (1990, idézi: Reis és Gubbins, 2003) úgy definiálja a tehetséges olvasókat, mint akik kivételes olvasási képességgel rendelkeznek, és a szövegbeli információk megértésének képessége is jobb a kortársaiknál. Dole és Adams (1983, idézi Reis és Gubbins, 2003) egy egyszerü definícióját adja a tehetséges olvasóknak. Szerintük azok a tehetséges olvasók, akiknek az olvasása hozzávetőlegesen két vagy még több évvel mutat jobb szintet a bemért, standardizált olvasási teszteken; vagy gyerekek, akik ugyan nem teljesítik ezt, de intellektuális tehetségek, s megvan bennük a magas szintü olvasásra való képesség lehetősége.

McIntosh (1982) áttekintette a tehetséges olvasók történetét az Egyesült Államokban. Szerinte a tehetséges olvasóknak - akiket gyakran nem vesznek észre - speciális olvasási instrukcióra 
van szükségük. Ezeket a gyerekeket az olvasási érdeklődésük különbözteti meg az átlagos olvasóktól, preferenciáik általában a természettudományok, a történelem, az életrajzi irodalom, az utazásról szóló beszámolók, a költészet, valamint az atlaszok és enciklopédiák. Kutatási eredményei szerint azok a tehetséges általános iskolás gyerekek, akik speciális programban vesznek részt, jobban teljesítenek, mint azok azon kiemelkedő olvasók, akik nem vesznek részt ilyen programban. Az adatok alátámasztják, hogy a tehetséges olvasók fejlesztésére differenciált programra van szükség. McIntosh 8 szempontban összegzi, hogy miben különböznek a tehetséges olvasók átlagos társaiktól, illetve milyen módszerek lehetnek alkalmasak a tehetséggondozásra: 1) A tehetséges olvasók általában a dekódolást magasabb szinten használják, és az iskolába lépéskor már elsajátították. Korán megértik a komplex fogalmakat. 2) A tehetséges olvasók többnyire belső kontroll attitüddel rendelkeznek, vagyis hisznek benne, hogy az elért eredményeik a képességeik és a viselkedésük eredménye. 3) Másfajta olvasási instrukciókra van szükségük, mint ami a hagyományos tantervben foglalt. 4) Az instrukcióknak a magasabb szintủ kognitív megértési készségek elsajátítását és fejlesztését kell a középpontba állítani. 5) Többre van szükség, mint egy képességorientált megközelítésre; kizárólag az olvasás technika oktatása nem elegendő! 6) A nekik szóló könyveket a nyelvi minőség alapján kell kiválogatni: a kognitív fejlődés elsődleges forrásai a komplex nyelvi struktúrák. 7) Az olvasási programoknak növelni kellene az olvasási kedvet. 8) A tehetséges olvasóknak szóló programnak magába kellene foglalnia az olvasnivalók széles választékát, és az olyan olvasási stratégiák tanítását, melyek a gyerekek tényleges képességeihez illeszkednek, nem az életkorukhoz vagy a teljesítményükre kapott osztályzathoz.

A tehetséges olvasó definíciójában, nincs tehát teljes egyetértés a szakirodalomban. Ami biztos, hogy nem minden az átlagostól pozitív irányba eltérő olvasásteljesítményt nyújtó gyermeket tekinthetünk tudományos értelemben tehetségesnek (Jackson és Roller, 1993). Jellemzőik ugyanis nagyon változatosak, és nincs két egyforma tehetséges diák. Ugyanakkor van néhány jellemzö, melyeket Reis és Gubbins (2003) a korábban is említett kutatásokat alapul véve az alábbi táblázatban (1. táblázat) foglaltak össze. 
1. táblázat: A tehetséges olvasók jellemzöi (forrás: Reis és Gubbins, 2003, 3.)

\section{A tehetséges olvasók fejlesztése}

Az 1993-ban Rust, Golombok és Trickey (idézi Csányi, 2007) által kidolgozott, Wechsler teszt kiegészítéseként elkészített WORD (Wechsler Objective Reading Dimensions) teszt egyik altesztje helyesírási, szóképolvasási és szövegértési feladatokat tartalmaz. Az angol nyelvü standard 4232 angol és amerikai tanuló vizsgálata alapján készült. Utólagosan a felmérésta standard bővítéseként több sajátos nevelési igényü tanulónál és a tehetségesek egy kis csoportján is elvégezték. A 93 tehetséges (átlagéletkort tekintve 12 éves) diákkal elvégzett vizsgálat szerint a kiemelkedő képességü gyerekek a átlaghoz képest 17,4\%-kal teljesítettek jobban. (Csányi, 2007).

A fejlesztésre vonatkozóan Polette (1982, idézi Reis és Gubbins, 2003) szerint a tehetséges olvasóknak magasabb szintű képzésben, fejlesztésben kell részesülniük a gondolkodás, a kritikai olvasás, a szókincsfejlesztés, a problémamegoldás, a képzelőerő terén, illetve az irodalom széles spektrumát kell megismertetni velük. Karnes és munkatársai (1978) olyan oktatási anyagot állítottak össze, amely gyakorlati ötleteket tartalmaz az olvasási tehetség fejlesztéséhez az óvodás gyerekeknél. Az olvasási készséget jelző tulajdonságok listáját olyan általános módszerek és eljárások leírásával kísérik, amelyek segítségével fejleszthetők az olvasási képességek, valamint amelyek támogatják az átmenetet a beszélt nyelv megértésétől az írásos megértéséig. Meghatározták a célterületeket és azokat a tevékenységeket, amelyekkel stimulálni lehet a tehetséges gyermek érdeklődését és képességét az olvasásra. A célokhoz tartozik a gyermek aktív és passzív szókincsének bővítése, az olvasási kedv felkeltése, az írott és beszélt nyelv közötti kapcsolat, valamint annak a ténynek a gyermekekkel való tudatosítása, hogy az olvasással hasznos információk birtokába juthatnak. Célul tüzték ki továbbá az $\mathrm{ABC}$ betüinek azonosítását, a nyelv ritmusa és hangja iránti érdeklődés fejlesztését, a szövegkörnyezetben rejlő segítség felhasználásának képességét, a szövegértés javítását, és a nyomtatott szöveg révén történő véleményalkotás segítését (Karnes és McBride, 1978).

Reis és Gubbins (2003) vizsgálatukat harmadik és hetedik évfolyamos tanulók körében végezték. A diákok és a tanítási módszerek megfigyelését 9 hónapon át végezték, amit a tanárokkal készített mélyinterjúkkal egészítettek ki. A kutatásuk középpontjában az állt, hogy mennyire állnak a tehetségesek rendelkezésére alternatív olvasási tantervek vagy újfajta 
módszerek. Megfigyelésük szerint a tanítási órákon az iskolai olvasókönyveket és egyéb olvasmányokat kombináltan alkalmazzák. Olvasási technikákra vonatkozó instrukciókat minden osztályban csak elvétve tapasztaltak. Csupán 3 osztályban voltak időnként - a helyi tantervnek megfelelöen - speciális, tehetséges olvasók számára kidolgozott feladatok. Ezen kívül csak két osztályban figyelték meg, hogy differenciált instrukciókkal segítik a tehetségesek olvasási technikáit. 7 osztályban semmiféle differenciált foglalkozást és feladatot nem kaptak a tehetséges olvasók a 9 hónap alatt. Annak ellenére, hogy számos erőforrás rendelkezésre állt, és a differenciált oktatási módszerek is ismertek voltak a pedagógusok számára, csak nagyon kevesen használták ezeket arra, hogy a tehetségesek szükségleteihez igazodjanak.

A szerzők példaként említik a kiscsoportos feladatmegoldásokat, melyek ugyan rendszeresen előfordultak, ám a csoportok létrehozásakor nem képeztek a tehetséges olvasókból külön csoportot, így ez a fajta munka nem okozott számukra kihívást. Véleményük szerint, ennél az is nagyobb kihívást és motivációt jelenthetett volna a tehetséges olvasóknak, ha ezidő alatt szabadon keresgélhettek volna kedvenc weblapjaikon vagy olvasmányaikban.

A mélyinterjúkban minden pedagógus beszélt arról, hogy nagy a nyomás az iskola és a fenntartó felöl, hogy "felhozzák a leggyengébb olvasók jegyeit". Ez a nyomás pedig azt eredményezi, hogy a legkevésbé kreatív és innovatív módszereket használják, mert ezektöl várják a jegyek javulását a gyenge olvasóknál.

Shaughnessy (1994) kiterjesztett irodalmi tevékenységet javasol a tehetséges olvasóknak szánt speciális programokba, mint például vendég előadók meghívása, kreatív írás gyakorlása, vagy az olvasottak összekötése filmekkel. Vizsgálatai szerint a legtöbb iskolának és tanárnak megvan a kellő szabadsága az olvasási anyagok kiválasztásához, így a diákok szükségleteihez igazodhatnak. Dooley (1993) felhívja rá a figyelmet, hogy két alapvető komponenssel kell rendelkeznie egy olyan programnak, mely a tehetséges olvasók számára készült: egyrészt gondoskodik az alaptanterv gyors feldolgozásáról, másrészt differenciált tantervvel dolgozik, vagyis dúsítja az anyagot. Levande (1993) szerint a fenti két komponens mellett figyelembe kellene venni az egyedi tulajdonságokat, és kihívások elé állítani az olvasásban tehetséges gyerekeket. A számos elterjedt módszer közül hármat emel ki: gazdagító triád modell (Triad enrichment model), érdeklödő olvasás program (Inquiry reading), junior program (Junior Great Books Reading and Discussion Program). 
A gazdagító modell 3 féle egymásra épülö tevékenységet takar. Az első lépésben a diák egy problémát, témát választ és azt feltérképezi. A második szakaszban olyan tanulási technikák és módszerek sajátít el, amik a korábban kutatásra kiválasztott téma mélyebb vizsgálatához szükségesek. A végső szakaszban a diák megvizsgálja az általa választott témát egyedül, esetleg kiscsoportos formában. Végül dokumentálja a tanulási folyamatot, például előadást tart, vagy ír róla egy beszámolót.

A 4 hetes érdeklödő olvasás program 3. osztályos kor után lehet bekerülni. A program lehetővé teszi, hogy a diákok egy számukra érdekes témát megvizsgáljanak: témát választanak, kutatják, majd prezentálják a többieknek. Levande rámutat, hogy ez a módszer kiválóan használható differenciált oktatásra - míg a többiek haladnak a hagyományos tananyaggal, a tehetségesek erre fordíthatják az időt.

A Junior program összegyüjti a 2-12 éveseknek szóló irodalmi olvasmányokat, melyek jól ismertek, kellően komplexek, strukturáltak és kihívást jelentenek a gyermekek számára.

Jackson (1988) szerint a korai olvasási képesség egy komplex képesség, és a részképességek tekintetében nagyon különböznek a gyerekek. Azt javasolja a szülőknek, hogy biztassák a tehetségesen olvasó gyerekeiket a „természetes és élvezetes” olvasásra. Amikor pedig iskolába kerülnek, az iskolai oktatásnak túl kell mutatnia a hagyományos programokon, és a fókuszt a kritikai és kreatív gondolkodásra kell helyezni a tehetséges olvasóknál.

Bár számos módszert és fejlesztőprogramot dolgoztak ki a tehetséges olvasók azonosítására és fejlesztésére, s a PIRLS vizsgálatban részt vevő országok közül többen (pl. Szingapúr, Szlovák Köztársaság, Litvánia) alkalmaznak a tehetséges gyermekekre szabott specifikus programokat, úgy tünik nincs igazán kialakult, kanonizált közoktatási módszere a korai tehetség gondozásának, illetve a korai olvasók szükségletei szerinti tanításnak (Kennedy és Mullis, 2007). A nemzetközi tendenciának megfelelően Magyarországon is a gyengébb, valamint atipikus fejlődést mutató olvasók felzárkóztatására helyezik a hangsúlyt, így például míg diszlexiások számára létezik a Meixner féle olvasástanítási módszer, a korai vagy tehetséges olvasók számára nem készült egységes oktatási program. A tehetséggondozó iskolák, programok többsége idehaza 5. osztálytól indul, azt megelőzően a gazdagító programok az elterjedtek, és leginkább a pedagógusok saját belátására, kreativitására bízzák a tehetséggondozást. 
A magyar olvasástanítás módszertana rendkívül gazdag². Az iskolák és a pedagógusok maguk választhatják meg, melyikkel dolgoznak. Jelenleg nincs tantervben rögzített módszer a közoktatásban a tehetséges gyermekek olvasástanítására. A pedagógus dönt, miképp tanítja ezeket a gyerekeket. Véleményünk szerint az egyéni haladási tempót biztosító módszerek (pl. Zsolnai módszer) használata (Adamikné, 2001), illetve olvasási stratégiák tanítása segítheti a korai és a tehetséges olvasók fejlödését. Kiemelten fontosnak tartjuk a tehetségek, így a tehetséges olvasók korai felismerését és gondozását. Egyre több program létezik, és egyre több pedagógus kapcsolódik be a tehetségfejlesztő munkába, ám még mindig sok tehetség kallódik el azáltal, hogy számukra nem elérhetőek ezek a fejlesztő módszerek.

\section{Összegzés}

Azon egyéneket, akik esetében az átlagostól pozitív irányban eltérő olvasásteljesítmény kiemelkedően fejlett magasabb rendủ kognitív funkciókkal párosul, tehetséges olvasóként definiálja a szakirodalom. E tanulmányban elöször bemutattuk a tehetségkutatás történetét, majd összegeztük egy eddig keveset vizsgált terület, az olvasásában tehetséges gyermekekkel kapcsolatos kutatások eredményeit. Ezt követően leírtuk a tehetséges olvasó jellemzőit, oktatási szükségleteit és fejlesztési lehetőségeit.

Az olvasásfejlődés egy folyamat, amely során először tanulunk, hogy olvasni tudjunk, majd olvasunk, hogy tanuljunk. A közoktatás első éveiben elsajátított alapvetö pszichológiai olvasási komponensek optimális fejlettsége szükséges ahhoz, hogy az olvasottakat

2 hangoztató-elemző-összetevő módszer, szóképes előprogrammal (RomankovicsRomankovicsné-Tóth-Meixner); globális módszer (Kutiné-Tóth-Ligeti); Nyelvi, irodalmi és kommunikációs módszer (Zsolnai); intenzív-kombinált olvasástanítási program (Lovász); Meixner módszer diszlexiás gyerekeknek; heurisztikus programozású olvasás- és írástanítási módszer (Tolnai); hangoztató-elemző-összetevő módszer, szótagolással (Esztergályosné); helyesejtésre alapozott elemző-összetevő olvasás- és írástanítás (Hernádiné); fonomimikát alkalmazó, szótagoltató első osztályos program (Ivánné); tizenkét osztályos komplex iskola elsős programja (Csupa betü, csupa szó; Danyiné); Báder programja: Ábécés olvasókönyv 6-7 éveseknek; integrált magyar nyelvi és irodalmi program (Adamikné-Gósy-Lénárd); vonalelemekből építkező kreatív betütanítási eljárás (Mádainé-Kertész) (Adamikné, 2001) 
alkalmazni, értelmezni s értékelni tudjuk. Az olvasás-szövegértés napjainkra egy olyan eszköztudássá vált, amelynek fejlettségi szintje meghatározza, hogy az egyének mennyire tudnak a társadalom és gazdaság produktív tagjaként funkcionálni. Mivel a magyar oktatási rendszer erősen szelektív és kutatások igazolják, hogy az alsóbb évfolyamokon gyengébben teljesítők a felsőbb osztályokban sem tudják utolérni a lemaradást, a korai olvasásfejlesztés mind elméletben mind gyakorlatban egyre nagyobb hangsúlyt kap s ennek megfelelően egyre több kutatás és módszertani próbálkozás irányul az eddigi modellek, módszerek személyre szabására. A szakirodalomban és a pedagógiai gyakorlatban nagyobb hangsúlyt kapnak a gyengébb vagy rendellenes fejlődési ívủ olvasók felzárkóztatására irányuló programok, míg a jobb teljesítményt nyújtó, valamit tehetséges társaik fejlesztését célzó módszerek ezidáig háttérbe szorultak.

A tehetséges olvasó sokféle meghatározásából kiderül, hogy széles spektrumon mozognak ezen gyermekek jellemzöi. Közös pontként rajzolódik ki a gyorsabb tanulás, a fejlettebb gondolkodás, az absztrakt fogalmak magasabb szintü megértése, a jobb problémamegoldás és átlagos tanulókhoz képest eltérő irodalmi érdeklődés. Mindemellett a tehetségesként azonosított olvasók olvasásteszteken elért eredményei is kiemelkedőek s az olvasás-szövegértés fejlettségi szintjük akár 2 évvel is meghaladhatja az életkori sajátosságok alapján feltételezett szintet, így felmerül a speciális, személyre szabott oktatás szükségessége. Jól kirajzolódik, hogy a tehetséges olvasó beazonosításához nem elegendő csupán az integratív mérési szemlélet alkalmazása, sokkal inkább az analitikus megközelítés és diagnosztikus mérőeszközök segíthetnek a további fejlesztésre váró készségek feltérképezésében.

A témával foglalkozó kutatók szerint a tehetséges olvasók differenciált és magas színvonalú oktatást igényelnek, változatos módszerekkel, érdeklődésük és intellektusuk színvonalának megfelelő széles irodalmi választékkal, sok önálló kutatással. Úgy tünik, a kutatók és a szakemberek felismerték, hogy a tehetséges diákok csoportján belül a tehetséges olvasókkal való speciális foglalkozás éppoly fontos, mint bármely más területen a tehetséggondozás. Kidolgoztak néhány - fentebb említett - módszert is a tehetséges olvasók fejlesztésére, ám ezek széleskörü elterjedése még várat magára. A legtöbb országban jelenleg nincsen kialakult és tantervben rögzített módja az olvasásban tehetséges gyermekek oktatásának, azonban összegezve a fejlesztöprogramok központi elemeit, látható, hogy a pedagógiai gyakorlatban leginkább a gazdagítás módszereivel élhetnek a pedagógusok, vagyis külön feladatokkal, egyéni foglalkozással segíthetik a tehetséges olvasókat. 


\section{ABSTRACT \\ Identifying the talented reader - psychological features and developmental methods}

Learning to read lays the foundation for future learning and understanding across all areas of the curriculum. The quality of this foundation undoubtedly has a marked influence on whether students will struggle or succeed in achieving academically in not only reading and writing, but also in other domains. Decades of reading research have provided a good blueprint for understanding how children learn how to read and a plethora of intervention programs were devised for helping poor readers overcome the bottlenecks during the developmental process. Nevertheless, in terms of reading research less focus and attention has been dedicated to talented readers whose performance is above average or who exhibit extraordinary skills in this domain. Identifying talented readers is a complex issue. As nowadays there is a growing attention to talent psychology, numerous national and international studies attempt to outline the general and field specific attributes of talent and offer opportunities and methods for further development for talented readers as well. The aim of the present study is to examine (1) models describing talents (2) the current findings in talent psychology and reading, (3) developmental methods and points for intervention for talented readers.

Keywords: talent, talented reader, reading literacy, individualized reading development programs

\section{Irodalom}

Adamikné Jászó Anna (szerk.) (2001): A magyar olvasástanitás története. Osiris Kiadó, Budapest.

Balogh László (2004): Iskolai tehetséggondozás. Kossuth Egyetemi Kiadó, Debrecen.

Brown, R., Pressley, M. (1994): Self-regulated reading and getting meaning from text: the transactional strategies instruction model and its ongoing validation. In: Schunk, D.H., Zimmerman, B. J. (szerk.), (1994): Self-regulation of learning and performance: Issues and educational applications. Hillsdale, NJ: Erlbaum, 155-181.

Catron, R. M., Wingenbach, N. (1986): Developing the gifted reader. Theory into Practice, 25(2), 134-140. 
Collins, N. D., Kortner, A. (1995): Gifted readers and reading instruction. ERIC Digest., ERIC Clearinghouse on Reading, English, and Communication, Indiana University.

Czeizel Endre (1997): Sors és tehetség. Fitt image és Minerva Kiadó, Budapest.

Czeizel Endre (2000): A tehetség korszerü genetikai értelmezése. In: Balogh László, Herskovits Mária, Tóth László (szerk.), A tehetségfejlesztés pszichológiája. Kossuth Egyetemi Kiadó, Debrecen, 9-23.

Csányi Yvonne (2007): Nagyothalló tanulók szövegértése. Gyógypedagógiai Szemle, 35(2), 81-89.

Csapó Benő (2007): Hosszmetszeti felmérések iskolai kontextusban - az első átfogó magyar iskolai longitudinális kutatási program elméleti és módszertani keretei. Magyar Pedagógia, 107(4) 321-355.

Csapó Benő, Józsa Krisztián, Steklács János, Hódi Ágnes, Csíkos Csaba (2012): A diagnosztikus olvasás mérések részletes tartalmi kereteinek kidolgozása: elméleti alapok és gyakorlati kérdések. In: Csapó Benő és Csépe Valéria (szerk.), Tartalmi keretek az olvasás diagnosztikus értékeléséhez. Nemzeti Tankönyvkiadó, Budapest, 189-218.

Csíkos Csaba (2006): Nemzetközi rendszerszintü felmérések tanulságai az olvasástanítás számára. In: Józsa Krisztián (szerk.), Az olvasási képesség fejlődése és fejlesztése. Dinasztia Tankönyvkiadó, Budapest, 175-186.

Dooley, C. (1993). The challenge: Meeting the needs of gifted readers. The Reading Teacher, 46(7), 546-551.

Fogarty, E. (2009): Precocious reading. In B. Kerr (ed.), Encyclopedia of giftedness, creativity, and talent. Thousand Oaks, CA: SAGE Publications, Inc., 696-699.

Gagne, F. (2004): Transforming Gifts into Talents: The DMGT as a Developmental Theory. High Ability Studies, 15(2), 119-147.

Gósy Mária (2008): A szövegértő olvasás. Anyanyelv-pedagógia, 1. sz. Letöltés ideje: 2008. 10. 26. http://www.anyanyelv-pedagogia.hu/cikkek.php?id=25.

Halsted, J. W. (1990). Guiding the gifted reader. ERIC Digest. ERIC Clearinghouse on Handicapped and Gifted Children Reston VA.,

Jackson, N. E. (1988): Precocious reading ability: What does it mean? Gifted Child Quarterly, 32(1), 200-204.

Jackson, N. E., Roller, C. M. (1993): Reading with young children. (Report Number 9302.) The National Research Center on the Gifted and Talented, University of Connecticut.

Józsa Krisztián, Steklács János, Hódi Ágnes, Csíkos Csaba, Adamikné Jászó Anna, Molnár Edit Katalin, Nagy Zsuzsanna és Szenczi Beáta (2012): Részletes tartalmi keretek az olvasás diagnosztikus értékeléséhez. In: Csapó Benő és Csépe Valéria (szerk.), Tartalmi keretek az olvasás diagnosztikus értékeléséhez. Nemzeti Tankönyvkiadó, Budapest, 219-249.

Karnes, M. B., McBride, G. F., Strong, P. S., Kemp, P., Kilbourn, B. (1978): Nurturing academic talent in early childhood: Reading. Institute for Child Behavior and Development, University of Illinois.

Kennedy, A. M., Mullis, I. V.S., Martin, M. O., Trong, K. L. (Ed) (2007): PIRLS 2006 Encyklopedia. A guide to reading education in the forty PIRLS 2006 countries. TIMSS $\&$ PIRLS International Study Center, Lynch School of Education, Boston College.

Khatena, J. (1992): Gifted: Challenge and response for education. F.E. Peacock Publisher INC., Illinois. Letöltés ideje: 2013. augusztus 23. http://timss.bc.edu/PDF/P06Encyclopedia.pdf

Levande, D. (1993): Identifying and serving the gifted reader. Reading Improvement, 30(3), 147-150.

McIntosh, M. E. (1982): An historical look at gifted education as it relates to reading programs for the gifted ERIC document, in: ERIC, ED 244472 
Mező Ferenc, Miléné Kisházi Edit (2003): Müvésztehetségek azonositása és gondozása. Borsod-Abaúj-Zemplén Megyei Pedagógiai Szakmai és Szakszolgálati Intézet, Miskolc.

Moore, M. (2005): Meeting the educational needs of young gifted readers in the regular classroom. Gifted Child Today, 28(4), 40-47.

Mönks, F. J. (2000): Hochbegabung im Kleinkindalter - Erkennen und Handeln. In: Kleine Kinder - Große Begabung. Hoch begabte Kinder erkennen und fördern. Möglichkeiten und Grenzen des Kindergartens, 25-37, BMW Group, München.

Mönks, F. J., Ypenburg, I. H. (1998): A nagyon tehetséges gyerekek. Akkord Kiadó, Budapest.

Mullis, I.V.S., Martin, M. O., Gonzalez, E. J. (2004): International Achievement in the Process of Reading Comprehension: Results from PIRLS 2001 in 35 Countries. Chestnut Hill, MA, Boston College.

Mullis, I.V.S., Martin, M.O., Kennedy, A.M., Foy, P. (2007): PIRLS 2006 International Report: IEA's Progress in International Reading Literacy Study in Primary Schools in Forty Countries. Chestnut Hill, MA. Boston College.

Nagy József (2006): Olvasástanítás: a megoldás stratégiai kérdései. In: Józsa Krisztián (szerk.): Az olvasási képesség fejlödése és fejlesztése. Dinasztia Tankönyvkiadó, Budapest. 17-42.

Nahalka István és Mózessyi Rebeka Dorottya (2011): Tehetségkutatás a gyakorlatban. A tehetséggondozás hazai és nemzetközi komparatisztikai kutatása. A kutatás keretei és elméleti kiindulópontjai. ELTE, Budapest. Letöltés ideje: 2013. szeptember 6. http://www.tehetség.elte.hu

National Assesment of Educational Progress (NAEP). (1998): Reading Framework for the National Assesment of Educational Progress: 1992-1998. Washington DC. Department of Education, Office of Educational Research and Improvement.

OECD (2000): Measuring Student Knowledge and Skills: A New Framework for Assessment. OECD, Paris.

OECD (2001): Knowledge and skills for life. First results from the OECD programme for international student assessment (PISA) 2000. OECD, Paris.

OECD (2010): PISA 2009 Results: What Students Know and Can Do - Student Performance in Reading, Mathematics and Science. (Volume I). OECD, Paris.

OECD (2013): PISA 2012 Assessment and Analytical Framework: Mathematics, Reading, Science, Problem Solving and Financial Literacy. OECD, Paris.

Páskuné Kiss Judit (2002): A másodoktatás szerepe a képességek fejlesztésében - különös tekintettel a tehetséggondozásra. In.: Dávid Imre, Bóta Margit, Páskuné Kiss Judit (szerk.), Tehetségkutatás. Kossuth Egyetemi Kiadó, Debrecen, 219-333.

Reis, S. M., Gubbins, E. J., Briggs, C., Schreiber, F. J., Richards, S., Jacobs, J., Eckert, R. D., Renzulli, J. S., Alexander, M. (2003): Reading instruction for talented readers: case studies documenting few opportunities for continuous progress. National Research Center on the Gifted and Talented University of Connecticut.

Renzulli J. S. (2002): Emerging Conceptions of Giftedness: Building a Bridge to the New Century. Exceptionality, 10(2), 67-75.

Renzulli, J. S., Park, S. (2000): Gifted dropouts. The who and the why. Gifted Child Quarterly, 44(4), 261-271.

Shaughnessy, M. (1994): Gifted and reading. ERIC document, in.: ERIC, ED 368145

Tóth Dénes és Csépe Valéria (2008): Az olvasás fejlődése kognitív pszichológiai nézőpontból. Pszichológia, 28( 1), 35-52.

Tóth László (1996): Tehetség-kalauz. Kossuth Egyetemi Kiadó, Debrecen.

Tóth László (1998): A tehetségesek tanitása. Kossuth Egyetemi Kiadó, Debrecen. 
Tóth László (2003): A tehetségfejlesztés kisenciklopédiája. Pedellus Tankönyvkiadó, Debrecen.

Treffert, D. A. (2011): Hyperlexia: reading precociousness or Savant skill? Distinguishing autistic-like behaviors from Autistic Disorder. WMJ, Vol. 110 (6)., 281-286. Letöltés ideje: 2013 augusztus

21.

https://www.wisconsinmedicalsociety.org/professional/savant-

syndrome/resources/articles/hyperlexia-reading-precociousness-or-savant-skill/

Valencia, S. W., Pearson, P.D. (1987): Reading assessment: Time for a change. The Reading Teacher, 40(8), 726-732. 
Lektori vélemények Döbör Ágota: Ki a tehetséges olvasó? Avagy minden kognitív téren tehetséges ember egyben tehetséges olvasó is? - Az olvasásban tehetségesek pszichológiai jellemzői c. cikkről

Lektor I.

A cikk nagyon fontos és mind elméleti, mind gyakorlati szempontból igen jelentős kérdéssel foglalkozik. Jól összegzi a szerző(k) által olvasottakat, így képet ad a témáról azok számára, akik angolul nem tudnak megfelelő szinten olvasni. Mint minden áttekintés, kiváló lehetőség arra, hogy a kérdéskörben járatlan olvasó információt kapjon, és - adott esetben - felkeltse az érdeklödését, és tovább olvasson a témában, jelen esetben a tehetséges olvasó kérdéseiről. Azt gondolom, hogy ez a cikk érdemes arra, hogy megjelenjen, de előtte szükséges egy alapos átdolgozás. Indokaimat az alábbiakban összegzem.

A cikk absztraktja, megítélésem szerint, nem a cikk tartalmát foglalja össze, inkább általában ír az adott téma kapcsolódásairól (pl. tehetség). A végén egyetlen mondatban összegzi a cikket. Talán jobb lenne röviden a cikk főbb gondolatait közölni az absztraktban.

A cikk szerkezetét a lektori javaslatnak megfelelően átalakítottuk. A jelenlegi absztrakt megírásakor törekedtünk arra, hogy tükrözze a cikk fö mondanivalóját és kövesse az átalakított szerkezetet. Az absztrakt kiindulópontját az a tételmondat képezi, hogy az olvasási képesség, illetve az olvasás-szövegértés avagy reading literacy (más-más terminológiát használnak, de napjainkban ugyanazt értik alatta: a különböző médiumok által közvetített írott szövegekben található információk felhasználását, értelmezését és értékelését) optimális fejlettségi szintje képezi az iskolai és társadalmi boldogulás egyik fö alappillérét. Ennek megfelelően számos fejlesztőprogramot dolgoztak ki hazai és nemzetközi kutatók, hogy a lemaradással küzdő tanulókat felzárkóztassák. Ezen programok mind a tipikus mind az atipikus/rendellenes fejlődés következtében fellépő hátrányt próbálják kiküszöbölni. Mindazonáltal kevés azon kutatások száma, amely a jó, illetve tehetséges olvasók továbbfejlesztésére irányul. 
Az olvasás pszichológiai és alkalmazási komponensei fejlettségi szintjének feltérképezésre számos megbízható, validált és sztenderdizált mérőeszköz áll rendelkezésre, azonban a tehetséges olvasó témakörével foglalkozó szakirodalom tanulságai szerint ezek a tesztek önmagukban nem elegendőek a tehetséges olvasó |beazonosításához.

Az absztrakt végén összegezzük tanulmányunk fó célját, mintegy keretet adva az olvasott tartalomnak.

A cikk szerkezete meglehetősen nehezen követhető, nem egyértelmű, hogy milyen logika mentén halad. A tehetséges olvasó jellemzésével indul, majd ez a hetedik oldalon (saját számlálás, nem találtam oldalszámokat) folytatódik. Közben sok egyébröl is esik szó a tehetséges olvasó kapcsán. Jó lenne átgondolni azt a logikai menetet, amelyet követve a szerző(k) ismerteti(k) a szakirodalomban található tényeket.

Sok tartalmi ismétlés fordul elő a szövegben, ezeket érdemes lenne ellenőrizni.

Az észrevétel helytálló. Az oldalszámozást pótoltuk s töröltük az ismétléseket.

Noha a szerző(k) megfogalmazásában egy nemzetközileg is kevéssé kutatott területtel foglalkozik(nak), valójában csupán az amerikai vonatkozó szakirodalom egyes megállapításait közlik. Jó lenne, ha mélyebb merítésben, más szakirodalmat is használnának.

Ez a szükítés ugyanis különösen feltünő, amikor a fejlesztésről írnak. Az amerikai olvasástanítás (és olvasástanulás) nagyon sok mindenben különbözik a magyarétól (de például a németétől vagy a horvátétól is). Így az ott leírtak tipikusan az amerikai rendszerben relevánsak. Javasolom az ezzel kapcsolatos (meglehetősen gazdag) magyar (olvasással általában és olvasástanítással foglalkozó nyelvészeti, pszicholingvisztikai és pszichológiai aspektusú) szakirodalmat is megemlíteni, sőt akár bemutatni. Jó lenne a nem csak angol anyanyelvü gyermekek esetében a tehetséges olvasóval kapcsolatos álláspontokat megismerni (feltételezem, hogy létezik legalább 1-2 ilyen tanulmány). 
A cikkben megemlítettük a magyar olvasástanítási módszereket, hivatkozva egy összefoglaló irodalomra. Az olvasás-szövegértés definiálásakor felhasználtuk a pszicholingvisztikai és nyelvészeti irodalmakat.

A tehetséges diákok és a korai olvasók olvasástanítására hivatalos ajánlás jelenleg nincs, a pedagógusok döntik el, miként fejlesztik a gyerekeket. A cikkben leírtuk, hogy azok a módszerek ajánlatosak, melyek egyéni haladást biztosítanak, és a pedagógiai gyakorlatban a gazdagítás módszere elterjedt.

Az az észrevétel, hogy főként az amerikai és angolszász kutatásokat mutatjuk be, miközben nemzetközi összefoglalást említünk, helytálló. Ennek megfelelöen a tanulmányt módosítottuk. Jelenleg a téma terjedelmessége miatt föként az amerikai és angolszász kutatásokról adtunk áttekintést. Egy következö tanulmányban a lektori javaslatnak megfelelően érdemes az európai - különös tekintettel a német - tanulmányok és módszertanok összefoglalását megtenni.

Jó lett volna megtudni a jelen cikk szerzőinek véleményét a kérdéssel kapcsolatban.

Véleményünket megfogalmaztuk.

Megjegyzés [YUN4]:

Részletmegjegyzések:

A 2. oldalon szerepel, hogy a tehetséges olvasók legalább két szinttel az életkorban elvárható szint felett olvasnak. Itt két problémát is látok. Mit jelent a szint? Osztályfok? (Megjegyzem, jóval később szerepel egy sztenderdizált teszttel meghatározott szintre utalás a szövegben.) A másik probléma maga az olvasás, illetve a folyamat definiálásának problémája. Sem az idézett szöveg, sem a jelen cikk nem ad meghatározást. Az olvasnak szó tehát mit takar? Technikai olvasást? Értő olvasást? Kritikai olvasást? Ezekről a cikk vége felé olvashatunk ugyan, de szerkezetileg nyilván sokkal elöbbre kellene kerülniük. Nagyon hiányzik, hogy végigvezessék az amerikai szakirodalomban egyébként ez jól megtalálható a beszédfeldolgozás és az olvasás, illetve az anyanyelv-elsajátítás összefüggéseit. Nehéz a tehetséges olvasóról megállapításokat tenni, amíg maguk a fogalmak nincsenek kellőképpen tisztázva. 
Az észrevétel helytálló. A javaslatnak megfelelően a bevezetőben tisztázzuk, hogy a szerzők mely definíciót veszik alapul a cikkben említett olvasás-szövegértés terminológia használatakor. Az olvasás-szövegértés meghatározásában követjük a hazai és nemzetközi keresztmetszeti és longitudinális nagymintás vizsgálatok (1. OECD PISA, IEA PIRLS, HELP/SZILP, Országos Kompetenciamérés) tartalmi keretében foglaltakat.

Mindazonáltal a kapcsolódó fogalmak (jó olvasó, hiperlexia) tisztázásakor megemlítjük, hogy az olvasás-szövegértés folyamata két egymással párhuzamosan fejlődő részböl/szintből tevődik össze (dekódolás és a szövegértelmezés). A szintek leírása valóban indokolt, ugyanis mindkét szakaszban tapasztalhatunk a tanulók részéről kiemelkedő, azaz az átlagostól pozitív irányba akár 2-3 szórásnyira eltérő, teljesítményt. A dekódoláshoz szükséges kognitív komponensek fejlettségi szintje bár eredményezhet kiemelkedő dekódolást, azonban ez még nem garantálja az értő olvasást. Erre bizonyíték a hiperlexia jelensége, amelyre még nem született egységes fogalmi meghatározás s atipikus vagy tipikus volta is tisztázatlan a témával foglalkozók körében.

Hiba az alábbi megállapítás magyarázat nélküli közlése: Ekkor a tempó átlagosan 250 szó/perc, ez nagyjából megfelel a beszédtempónak. Ez egy igen gyors (amerikai angol?) beszédtempó, a brit angolt átlagosan 200 szó/perc körülire adják meg. A magyarul olvasó viszont a magyarra is értelmezheti a megállapítást, pedig a magyarban a 170 szó/perces beszédtempó már alig érthető. Ez azért is fontos, mert a cikk viszonylag hosszan foglalkozik két tehetséges olvasó olvasási tempójával.

Az észrevétel helytálló. A téma tudományossága megkérdőjelezett, a tehetséges olvasó témájához sem kapcsolódik szorosan, így ezt a részt töröltük.

Nem szerencsés a skill szó használata (nem feltételezhető, hogy minden leendő olvasó megérti). A kéne szó is kerülendő (inkább: kellene). Az aktivitás pedig magyarul tevékenység.

Az észrevétel helytálló. Javítottuk. 
Megismételve a véleményemet: a cikket alapos átdolgozás után érdemesnek tartom a közlésre. 
Lektor II.

\section{Általános vélemény}

Az olvasás terén az atipikus fejlődés kutatása szinte kizárólag a fejlődési diszlexiára irányul. A kézirat szerzői helyesen ismerték fel, hogy a másik véglet, a tehetséges olvasók fejlődéséről nagyon kevés tudományosan megalapozott ismerettel rendelkezünk, ráadásul ezen kutatási eredmények magyar nyelven nem hozzáférhetők. A tanulmány tehát - amely lényegében a fiatal tehetséges olvasók pszichológiai jellemzőivel kapcsolatos külföldi szakirodalom rövid, lényegretörő összefoglalása - mindenképpen hiánypótlónak tekinthető, és a Pszichológia folyóiratban való megjelenése által elősegítheti a téma intenzívebb jelenlétét a hazai szakmai körökben.

A kéziratban a témához tartozó tartalmi elemek szinte mindegyike helyet kapott (az olvasás szintjei, az olvasási tehetség meghatározása, a tehetséges olvasók pszichológiai jellemzői, a tehetségek olvasók oktatása), viszont véleményem szerint a bemutatásuk sorrendjének változtatásával, a kézirat jobb tagolásával a követhetőség, a lényeges üzenetek megértése sokat javulna. Az ezzel kapcsolatos részleteket lásd az Észrevételek és kérdések pontban.

\section{Észrevételek és kérdések}

\section{A kézirat központi mondanivalója}

1) A cím jelenlegi formájában egyrészt túl hosszú, másrészt félrevezető is: a kézirat tartalma nem illeszkedik pontosan a címhez. A cím azt sugallja, hogy a kézirat központi témája annak a kérdésnek a tisztázása, hogy melyek a tehetséges olvasók megkülönböztető pszichológiai jegyei, illetve hogyan (mely jellemzők mentén) és milyen mértékben térnek el a tehetséges olvasók a más területen tehetséges személyektől. Ehhez képest a kéziratnak csupán egyik fejezetpontja szól a pszichológiai jellemzőkről (kb. 7300 karakter terjedelemben), az általános értelemben vett tehetség (amelyet a szerzők egyébiránt csak érintőlegesen említenek) és az olvasási tehetség elkülönítéséről mindössze két bekezdésben olvashatunk, míg például a speciális olvasásfejlesztési programok bemutatásának a szerzők egy külön fejezetpontot szenteltek, az eddigiekhez képest igen hosszú, 9500 karakteres terjedelemben. Azt javaslom, hogy a szerzők gondolják át a címválasztást, esetleg változtassanak a tartalmi hangsúlyokon, ha a címet változatlanul hagyják. Szintén javaslom a cím olyan megformálását, amelyből kiderül, hogy a továbbiakban kizárólag fiatal (iskoláskorú) olvasókról esik szó.

Az eredeti kéziratban benyújtott cikkben valóban indokolatlan, a cím által sugallt tartalomtól és logikai felépítéstől eltérő hangsúlyt kaptak az egyes részek. Ennek megfelelően 
egyrészről javítottuk a címet, illetve a fejlesztési lehetőségek részben taglalt korosztályt is belefoglaltuk. Másrészről a cikk szerkezetén és arányain is változtattuk a követhetőség, érthetőség mentén, egyúttal figyelembe véve a tudományos közlési stílus normáit.

2) Az előző ponthoz részben kapcsolódik, hogy a kézirat elején olvasható összefoglaló (amely az absztrakt, azaz kivonat szerepét kellene betöltse) sokkal inkább hasonlít egy bevezetésre, mint egy tömör összefoglalóra. Ráadásul éppen ebben a részben teszik fel a szerzők azt a kérdést („Feltehetjük a kérdést, vajon minden tehetséges diák egyben tehetséges olvasó is, vagy ezt a faktort is egy külön tehetség típusként kell kezelnünk, akár a matematikai, zenei, képzőművészeti, vagy épp sport tehetségeket?"), amelyre a kézirat tulajdonképpen nemhogy nem válaszol, de a kérdés alaposabb körbejárása is elmarad. A kézirat ugyanis sokkal inkább arról szól, hogy miben különböznek a tehetséges olvasók az átlagos olvasótól, mind pszichológiai jellemzőik, mind az oktatási igényük terén. Hangsúlyozom, hogy nem arról van szó, hogy ez utóbbi téma ne lenne éppoly érdekes, mint az, amelyre a szerzők által feltett kérdés vonatkozik. A problémát a kérdésfelvetés és a kifejtés diszkrepanciája okozza. Emiatt kézirat absztraktját mindenképpen átírásra javaslom.

A cikk szerkezetét és címét a lektori javaslatnak megfelelően átalakítottuk. A jelenlegi absztrakt megírásakor törekedtünk arra, hogy tükrözze a cikk fő mondanivalóját és kövesse az átalakított szerkezetet. Az absztrakt kiindulópontját az a tételmondat képezi, hogy az olvasási képesség, illetve az olvasás-szövegértés avagy reading literacy (más-más terminológiát használnak, de napjainkban ugyanazt értik alatta: a különböző médiumok által közvetített írott szövegekben található információk felhasználását, értelmezését és értékelését) optimális fejlettségi szintje képezi az iskolai és társadalmi boldogulás egyik fő alappillérét. Ennek megfelelően számos fejlesztőprogramot dolgoztak ki hazai és nemzetközi kutatók, hogy a lemaradással küzdő tanulókat felzárkóztassák. Ezen programok mind a tipikus mind az atipikus/rendellenes fejlődés következtében fellépő hátrányt próbálják kiküszöbölni. Mindazonáltal kevés azon kutatások száma, amely a jó, illetve tehetséges olvasók továbbfejlesztésére irányul.

Az olvasás pszichológiai és alkalmazási komponensei fejlettségi szintjének feltérképezésre számos megbízható, validált és sztenderdizált mérőeszköz áll rendelkezésre, azonban a tehetséges olvasó témakörével foglalkozó szakirodalom tanulságai szerint ezek a tesztek önmagukban nem elegendőek a tehetséges olvasó beazonosításához.

Az absztrakt végén összegezzük tanulmányunk fö célját, mintegy keretet adva az olvasott tartalomnak. 
3) A kézirattal kapcsolatos fentebbi aggályok nagymértékben csökkennének, egyúttal az egész kézirat követhetősége nagymértékben javulna, ha a kézirat a jelenlegi, némileg „in medias res” stílusú kezdés helyett valódi bevezetéssel indulna. (A kézirat összefoglalója [kivonata, absztraktja] nem pótolja a bevezetést, noha a kettő között akár szószerinti egyezések, közös szakaszok is lehetségesek). Javaslatom tehát az, hogy a szerzők egy bevezető szakaszban vezessék fel a témaválasztás indokoltságát, illetve határolják be a tárgyalni kívánt kérdések körét.

A javaslatnak megfelelően pótoltuk, illetve kiegészítettük, módosítottuk a bevezetőt, amelyben felvezetjük a témaválasztás indoklását s pontosítjuk jelen tanulmány célkitűzéseit. Mindemellett a bevezetőben leírjuk milyen teljesítménymérési programok eredményei emelték az olvasás-szövegértés fontosságát mind a szülök, szakemberek és oktatáspolitikai döntéshozók figyelmének középpontjába. Továbbá emlitést teszünk arról, hogy ezidáig kutatómunkánk során nem bukkantunk magyar nyelvű, a témában született szintetizáló szakirodalmi tanulmányra, így jelen tanulmány hiánypótlónak tekinthető.

\section{A kézirat szerkezete}

1) Tekintettel a kézirat központi témájával kapcsolatos bizonytalanságra, a kézirat szerkezetét és a gondolati ívet érintő észrevételeim és javaslataim úgy értelmezendők, hogy a kézirat központi témájának a tehetséges olvasók pszichológiai jellemzőinek, valamint a tehetséges olvasóknak az oktatási rendszerrel szemben támasztott speciális igényeinek bemutatását ítéltem meg.

Amennyiben ez a feltételezésem helyes, úgy a tárgyalást érdemes lenne az olvasás pontosabb meghatározásával kezdeni (amelyet a szerzők csupán az utolsó előtti [8.] oldalon tesznek meg, lásd: „Itt érdemes megállni egy kicsit, és áttekinteni az olvasás szintjeit!”). Ez azért is javasolt, mert maguk a szerzők a második oldalon így fogalmaznak: „A kutatások egy része definiálni kívánja az olvasás terén tehetséges gyerekeket, illetve összegyüjteni a tehetséges olvasók és szövegértők [kiemelés tőlem] jellemzőit.” Ez alapján a szerzők külön kezelik az olvasást és a szövegértést, a későbbiekben viszont ilyen megkülönböztetést nem tesznek. Ez azért is lényeges kérdés, mert a fejlödési diszlexiás és a tipikusan fejlődő olvasókkal kapcsolatos kognitív pszichológiai szakirodalomban egyértelmúen szétválik a szószintű olvasás (dekódolás és szófelismerés) és a szövegértés kutatása, illetve az olvasás ezen két szintjén mérhető egyéni teljesítmény mögött álló kognitív faktorok részben eltérőek (sőt, pl. egy dekódolásban kiemelkedően teljesítő tanuló közel sem biztos, hogy egyúttal jó szövegértő is). 
Az észrevétel helytálló. A javaslatnak megfelelően a bevezetőben tisztázzuk, hogy a szerzők mely definíciót veszik alapul a cikkben említett olvasás-szövegértés terminológia használatakor. Az olvasás-szövegértés meghatározásában követjük a hazai és nemzetközi keresztmetszeti és longitudinális nagymintás vizsgálatok (1. OECD PISA, IEA PIRLS, HELP/SZILP, Országos Kompetenciamérés) tartalmi keretében foglaltakat.

Mindazonáltal a kapcsolódó fogalmak (jó olvasó, hiperlexia) tisztázásakor megemlítjük, hogy az olvasás-szövegértés folyamata két egymással párhuzamosan fejlődő részből/szintből tevődik össze (dekódolás és a szövegértelmezés). A szintek leírása valóban indokolt, ugyanis mindkét szakaszban tapasztalhatunk a tanulók részéről kiemelkedő, azaz az átlagostól pozitív irányba akár 2-3 szórásnyira eltérö, teljesítményt. A dekódoláshoz szükséges kognitív komponensek fejlettségi szintje bár eredményezhet kiemelkedő dekódolást, azonban ez még nem garantálja az értő olvasást. Erre bizonyíték a hiperlexia jelensége, amelyre még nem született egységes fogalmi meghatározás s atipikus vagy tipikus volta is tisztázatlan a témával foglalkozók körében.

A cikkben kiemeljük, hogy a tehetséges olvasó már nem olvasni tanul, hanem olvas, hogy tanulhasson, tehát az értő olvasásban nyújt kiemelkedő teljesítményt. Azt is hangsúlyozzuk, hogy bár mind a tehetséges olvasó mind a jó olvasó kiemelkedő szövegértési képességgel rendelkezik (amely alapja a dekódoláshoz szükséges kognitív/pszichológiai komponensek optimális fejlettségi szintje), a jó olvasó a stratégiahasználat és olvasás iránti pozitív attitüd mentén, míg a tehetséges olvasó emelett mutatja a tehetségesekre jellemzö általános fejlődési előnyt (magas intelligencia, gyorsabb tanulás, könnyebben megtalálják és megoldják a problémát, jobb nyelvi megértést mutatnak, a komplex fogalmakat előbb megértik, kiterjedt szókincset használnak, a jelek és szimbólumok közti kapcsolatok megértésében ügyesebbek kortársainál, érdeklődésük speciális: atlaszok, szótárak, enciklopédiák gyakori használata jellemző).

2) A szerzők külön fejezetpontot szenteltek az eidetikus memóriának és a gyorsolvasásnak. Ez a jelenség tudományos körökben a megfelelö színvonalú empirikus bizonyítékok hiánya miatt olyan mértékben vitatott, hogy véleményem szerint nem érdemes ilyen súllyal szerepeltetni a tehetséges olvasókról szóló szakirodalmi összefoglalóban. Ezt erősíti az is, hogy maguk a szerzők is egyetlen, 1969-ben megjelent tanulmányra hivatkoznak ebben a részben. 
A kifogásolt részt a lektori javaslatnak megfelelően töröltük.

Hiányolom viszont, hogy a tehetséges olvasók bizonyos csoportjairól, például a hiperlexiás gyerekekől és a korai olvasókról (az angol nyelvü szakirodalomban precocious reader) egyáltalán nem esik szó a kéziratban, noha ezen speciális csoportok pszichológiai jellemzőinek ha nem is könyvtárnyi, de számottevő - ráadásul tudományos kritériumok alapján is igen színvonalas - szakirodalma létezik.

A cikk középpontjában a tehetséges olvasó áll, azonban a fogalmi tisztázás érdekében a javaslatnak megfelelöen említést tettünk a korai olvasókról, illetve a hiperlexiás gyermekekről is. A hiperlexias olvasó teljesítménye gyors és mechanikus olvasás tekintetében valóban megtévesztő lehet, azonban a hiperlexias gyermek szövegértésbeli gyengeségei, valamint más területeken mutatott rendellenességei egyértelműen megkülönböztetik a tehetséges olvasó jellemzőitől.

A korai olvasókkal kapcsolatos külföldi szakirodalom egyre gyarapodik, s egyes szerzők a korai olvasókat a tehetséges olvasókkal azonosítják, s a fogalmakat szinonímaként kezelik, míg mások két külön csoportként definiálják a korai és tehetséges olvasókat. Jelen tanulmánynak nem fókuszpontja e két kiemelkedően teljesítő tanulói csoport jellemzése és vizsgálata, így törekedtünk a témakörök tanulmányunk szempontjából releváns aspektusainak bemutatására.

4) A kézirat szerkezetének átlátását az is nehezíti, hogy a kézirat tagolása viszonylag szegényes és nem kellően következetes. Esetenként a fejezetpont címe nem fedi a fejezetpont tartalmát, például a „Tehetséges olvasók empirikus vizsgálata, speciális olvasásfejlesztő programok" fejezetcím alatt egyetlen bekezdés szól arról, hogy a tehetséges tanulók (a szövegből nem derül ki, hogy milyen értelemben tehetségesek) egy nagymintás vizsgálatban hogyan teljesítettek egy standard olvasás- és helyesírásteszten, majd a speciális olvasásfejlesztő programok áttekintése után a szerzők egy oldalon keresztül taglalják az olvasás szintjeit.

A javítás során törekedtünk a logikusabb szerkezeti felépítésre és a fejezetcímeket is igyekeztünk a tartalomnak megfelelöen megfogalmazni.

A tehetséges olvasó definiálására nagyobb hangsúlyt fektettünk, az említett alcímet a tartalomnak megfelelően módosítottuk. Az olvasás szintjeiről szóló részt itt töröltük, a szerkezetileg megfelelő helyen definiáltuk az olvasás-szövegértés fogalmát. 


\section{Egyéb észrevételek, javaslatok}

1) A hivatkozáslistában a címek írásmódja nem következetes (esetenként a szerzők minden szót nagybetűvel kezdenek, máshol csak a mondatkezdő szót - javaslom az utóbbi változat alkalmazását).

A javaslatnak megfelelöen javítottuk.

2) A harmadik oldalon a ,skill” szó helyett a magyar megfelelő (készség vagy képesség, a szerzők által hangsúlyozni kívánt jelentéstartalomtól függően) használatát javaslom.

A javaslatnak megfelelően javítottuk.

3) Az angol nyelvü összefoglaló helyenként olyan fordulatokat, kifejezéseket tartalmaz, amelyek egy angol olvasó számára rendkívül szokatlanok, sőt akár félrevezetőek lehetnek (pl. „reading and its issues”, ,as an assumption it can be concluded”). Javaslom, hogy a magyar nyelvü összefoglaló átírása után az angol változat elkészítéséhez vegyék igénybe angol nyelvü (vagy az angolt magas szinten beszélő) lektor segítségét.

Mind az angol mind a magyar nyelvü absztraktot átfogalmaztuk s az angol nyelvü verziót egy, az angol nyelvet anyanyelvi szinten beszélő és a szaknyelvet ismerő lektorral korrigáltattuk.

Összességében a tanulmányt a téma és a kifejtés általános színvonala okán - a központi mondanivaló és a szerkezet kapcsán megfogalmazott hiányosságok korrigálás után - publikálásra érdemesnek tartom. 